\title{
MANICHAEISM: ITS SOURCES AND INFLUENCES ON WESTERN Christianity
}

\section{Author:}

Johannes van Oort ${ }^{1,2}$

\section{Affiliations:}

${ }^{1}$ Faculty of Theology: Church History, University of Pretoria, South Africa

${ }^{2}$ Faculty of Theology, Chair for Ecclesiastical History, Utrecht, Netherlands

Correspondence to: Johannes van Oort

e-mail:

oort0109@planet.nl

\section{Postal address:}

Faculty of Theology,

University of Pretoria

Pretoria, 0002, South Africa

\section{Keywords:}

gnostic-Christian; Futtuq; asceticism; Codex Manichaicus Coloniensis; Mani

\section{Dates:}

Received: 10 July 2009

Accepted: 25 Nov. 2009

Published: 16 Dec. 2009

How to cite this article: Van Oort, J., 2009,

'Manichaeism: Its sources and influences on western Christianity', Verbum et Ecclesia 30(2), Art. \#362, 5 pages. DOI: $10.4102 /$ ve.v30i2.362

\section{This article is available} at: http://www.ve.org.za

(c) 2009. The Authors. Licensee: OpenJournals Publishing. This work is licensed under the Creative Commons Attribution License.

\section{ABSTRACT}

The aim of this paper is twofold. First, it will discuss the origins of Manichaeism, a gnostic-Christian world religion that was founded by the prophet Mani (216-276). My discussion of the origins of Manichaeism may serve as an excellent example to illustrate what 'Gnosis' or 'Gnosticism' actually was. Second, the paper will outline how Manichaeism, being an alternative form of Christianity and even an alternative Christian Church, seemed to have exercised a considerable influence on Catholic Christianity.

\section{INTRODUCTION}

Already in Late Antiquity, Manichaeism had become a world religion. This means that in its Manichaean form Gnosticism was once a real world religion, i.e., a world-wide and distinct gnostic community or Church (ekklèsia) with its many thousands and, later on, even millions of adherents. It had its own leader, bishops and priests; its own liturgy and rites; its own canonical Scriptures; and even its own and very attractive art (Van Oort 2002, 2008). Manichaeism spread from the region of Babylonia in Southern Mesopotamia (= the south of present-day Iraq) as far as the Atlantic in the West and the Pacific in the Far East (de Stoop 1909; Lieu 1994; Lieu 1998). It had adherents in Egypt, Roman North Africa, Spain, Gaul, Italy, the Balkans and, in the end, even along the South China Coast. Its history covers the period from the beginning of the third century CE to modern times. Even recently, until the middle of the previous century, 120 Manichaeism was forbidden by law in Vietnam (Kawerau 1967:51).

\section{THE ORIGINS OF MANI AND MANICHAEISM: AL-NADÎM AND THE CODEX MANICHAICUS COLONIENSIS}

In order to give an outline of the main features of this gnostic Church, it seems appropriate to start from the very beginning. There was once a certain historical figure called Mani. He was, as he styled himself, a prophet 'from the land of Babylon' (Ort 1967:73-74). Mani, or by his Syriac name: Manî hajjâ, 'the living Mani' was born in 216 CE. Several antique sources even state the exact day of his birth - Sunday, 14 April. For some time, we have also had precise information about the place where he was born, namely near the southern Mesopotamian town of Seleucia-Ctesiphon. This capital city, so famous in Late Antiquity, was located not far from present-day Baghdad.

At the beginning of the third century CE, some ascetic Jewish-Christian sects were found in those regions. From Mohammed Ibn al-Nadîm, a Muslim writer who lived at the end of the 10th century, we have an important report on the origins of Mani (Dodge 1970:773 ff.). He tells of a certain person named Futtuq, a resident of the 'Twin-Cities' (i.e., Seleucia-Ctesiphon), who joined a baptizing sect in response to a call to asceticism. This Futtuq is said to have been a native of Hamadhân [i.e., the ancient city of Ecbatana], and his wife Mays, or Marmaryam, is reported to be related to the formerly ruling house of the Arsacids.

One day, while Futtuq was worshipping in a temple of idols, he heard a loud voice admonishing him not to eat meat, nor to drink wine, nor to have intercourse with women. This happened a number of times during the following three days. Futtuq was eventually won over by this voice and consequently joined a sect known as Mughtasilah - those who wash (or: baptize) themselves. His wife Maryam was pregnant when Futtuq decided to join this baptist sect, and in due course she gave birth to their son. Fihrist or Catalogue in which al-Nadîm reports these things reads as follows:

Then his father sent and brought him to the place where he was, so that he was reared with him, in accordance with his cult. Even when young, Mani spoke with words of wisdom and then, when he was twelve years old, there came to him a revelation. According to his [= Mani's] statement it was from the King of the Gardens of Light (...). The angel bringing the revelation was called the Tawm, which is a Nabataean word meaning 'Companion'. He said to him, 'Leave this cult, for thou art not one of its adherents. Upon thee are laid purity and refraining from bodily lusts, but it is not yet time for thee to appear openly, because of thy tender years'. When he had completed his twenty-fourth year, the Tawm came to him saying, 'The time is fulfilled for thee to come forth and to give the summons to thy cause'.

(Dodge 1970:774)

Al-Nadîm continues to relate how Mani, at the age of twenty-four, broke away from the Mughtasilah and formed his own sect with his father and a handful of fellow Baptists. After this account, al-Nadîm writes of the history and the doctrines of Mani and the Manichaeans on the subsequent pages of his Fihrist he completed in Baghdad by either the year 988 or 989 (Dodge 1970:xxi).

It must be noted that, even in modern times, al-Nadîm's account has provoked great scepticism. To many scholars, the gnosis of Manichaeism seemed to be an offshoot of a kind of dualistic Iranian religion that was closely connected with Zoroastrianism. Evidently, the testimony of al-Nadîm did not support this view. The opinion or even dogma of the so-called 'History of Religion School' on 
the Iranian origin of Manichaeism (Colpe 1961; Verheule 1973:159ff) has now definitely turned out to be wrong, however. Al-Nadîm's account has been confirmed magnificently by the discovery of the so-called Cologne Mani Codex. Since a few years we know that Mani was indeed reared in a Baptist community in Southern Mesopotamia. Moreover, we now know that this sect was a Jewish-Christian one and that the origins of Mani's gnostic-dualistic world religion should be explained from this background. All this is due to the recent discovery of a unique Manichaean document, the so-called Codex Manichaicus Coloniensis or CMC.

I believe that it must be stated in no uncertain terms that, in order to understand the origins of Manichaeism, the CMC is of crucial importance. This document was discovered shortly before 1970 in Egypt. It came into the possession of the University of Cologne; hence its name. It is the world's smallest parchment codex. Its pages measure only $4.5 \mathrm{~cm}$ by $3.5 \mathrm{~cm}$ and the writing on them is $3.5 \mathrm{~cm}$ by $2.5 \mathrm{~cm}$. Despite its minute format, Manichaean scribes managed to copy an average of twenty-three lines of Greek majuscules onto each page.

The first preliminary report on the $C M C$ was given by the German scholars Albert Henrichs and Ludwig Koenen in a now famous 1970-issue of the Zeitschrift für Papyrologie und Epigraphik (Henrichs \& Koenen 1970). A complete critical edition of the CMC appeared in the year 1988 as Der Kölner Mani Kodex (Koenen $\mathcal{E}$ Römer 1988). Ever since the publication of this document there has been an ongoing scholarly evaluation of and debate on the correct interpretation of the text (Van Oort 1996b). A final academic edition with extensive annotations is still awaited for.

The CMC is written in Greek. It has as its running title on each two subsequent manuscript pages: PERI THS GENNHS / TOY $\Sigma \Omega M A T O \Sigma$ AYTOY, i.e., Peri tês gennês / tou sômatos autou. This may be translated as 'On the genesis / of his body'. How might this be interpreted? Two main views have emerged as a result of the ongoing scholarly debate regarding the CMC. According to one opinion, 'his body' refers to Mani's physical body and 'genesis' (génna) could be translated as 'procreation'. Several passages in the Codex may support this view. The other opinion claims that the title of the CMC is already an echo of the Pauline elements so evident in the Codex. As the apostle Paul in his letters described the Church as the body of Christ, similarly the Manichaean Church (ekklèsia) is described as the body of Mani (Van Oort 2004; Van Oort \& Quispel 2005:87-89). From this perspective the Codex may be interpreted as constituting the first part of a history of the early Manichaean Church.

It is difficult to come to a final decision as to which opinion is correct. Most scholars are partial to the first interpretation (Van Oort 1996b). The extant pages of the Codex have, as their main theme, the story of young Mani's sojourn among the Baptists that also recounts his earliest missionary journeys after his final break with the sect at the age of twenty-four (Römer 1994).

It is essential to note that the $C M C$ is not the work of one single author, but comprises excerpts from the testimonies of Mani's closest disciples and early followers. Just as the Evangelists gave their account of the life and the works of Jesus - or better: their account of Jesus' 'deeds and words' (cf. Acts 1:1), so in the CMC these earliest witnesses give their account of Mani's deeds and words. And, just like one Gospel harmony was created from several Gospels as is, for instance, the case with the Diatessaron of Tatian (c. 120-c. 180; Petersen 2005, 2008), so in the CMC we have a compilation and redaction of the earliest testimonies of Mani's deeds and words Among the names of the Manichaean witnesses which have been preserved are Salmaios the Ascetic, Baraies the Teacher, a certain Timotheos, Abjesous the Teacher, Innaios the brother of Zabed, a certain Za[cheas?], Koustaios the Son of the Treasure of Life, and Ana the Brother of Zacheas the Disciple. From the number of different authors of the original sections, it must be concluded that Mani used to speak frequently and at length about himself and about his supernatural experiences to his closest disciples. In the $C M C$ these earliest disciples appear to serve as trustworthy witnesses of Mani's deeds and words

It is something of a revelation to analyse the contents of the $C M C$ and to detect the most essential origins of Mani and his gnostic-Christian Church (Van Oort E Quispel 2005). We cannot enter into all details here, but some of the main facts could be mentioned. First, we now see how well-founded and in essence reliable Ibn al-Nadîm's testimony is, for according to the CMC Mani grew up among 'Baptists'. We also learn from the new Codex that they performed daily ablutions on themselves and on their food (CMC 80:1-3; 80:23-83:13; 88:13-15). In addition, their religion is referred to as 'the Law'. Nomós suggests that the community lived in accordance with the Jewish Law (e.g. CMC 20:9-11; 87:16-18; 89:11-13). Moreover, these Baptists appealed to 'the traditions of the Fathers' (CMC 87:2-7; 91:4-9). These characteristic expressions in the passages indicated refer to Jewish traditions.

Another indication of the Jewish roots of the community is that their members observed the 'Rest of the Hands' (CMC 102:15). This seems to refer to the observance of the Jewish Sabbath, probably is also this custom which can be found in later Manichaeism, known as 'the Seal of the Hands', observed by the Manichaean Elect. It meant that they abstained from agricultural work in order to refrain from damaging the divine light elements present in the earth and its fruits. Moreover, in a passage from Baraies 'the Teacher', one of the Manichaean authors from which the compiler of the $C M C$ edited his work, no less than five Jewish apocalyptic writings are quoted: an Apocalypse of Adam, an Apocalypse of Sethel, an Apocalypse of Enos, an Apocalypse of Sem and an Apocalypse of Enoch (CMC 48:16-60:7; cf. Gruenwald 1983:31ff; Frankfurter 1997; Reeves 1991).

The religious group described in the Cologne Mani Codex apparently acknowledged a certain Alchasaios (CMC 94:10.23 $95: 13 ; 96: 13.19 ; 97: 3.13 .15)$ as the founder of their rule. They were followers of the well-known Jewish-Christian prophet Elxai or Elchasaios (Van Oort 2008) and thus can rightly be termed Elchasaites or Elkesaites (contra Luttikhuizen 1985). Again this appears to support al-Nadîm's observation that the community of the Mughtasilah was instituted by a certain al-Hâsîh, a Jewish-Christian prophet said to have lived at the beginning of the second century. Thus Mani was brought up and educated in a Jewish-Christian community, a community of Jews in which Jesus was accepted as the promised Messiah. Virtue of his Jewish background we can say with some certainty that he lived according to the Mosaic law, which in turn may lead us to assume that he was circumcised.

It was, however, against this Law (Nómos) that Mani protested and thus became a gnostic. In the $C M C$, this break with the legalistic religion of his youth is recounted vividly, even dramatically. We find in Mani's own words (handed down by his closest disciples) what kind of gnostic experience inspired him. He claims that, since his early youth, he had come under special divine protection and instruction. Angels and powers of holiness were entrusted with his safekeeping. He also received visions and signs (e.g. CMC 3ff). All this may seem highly unusual from a modern point of view, but in the apocalyptic Jewish milieu in which Mani was brought up such experiences appears to have been quite common.

One of these divine messengers appears to have been Mani's special protector. This was his 'Syzygos', 'Twin', 'Companion' or guardian angel, the figure described in Manichaean teaching as an emanation of the Jesus of Light, who in turn is an emanation of the 'Nous' or 'divine Intellect' (Van Tongerloo $\mathcal{E}$ Van Oort 1995). Between the young Mani and his Syzygos grew an intimate relationship, which he praises in moving poetry:

and he who is the most trusty

him I received piously 
and him I acquired as my own property.

Him I believed

and he belongs to me

he is a good and kind guide.

Him I recognized

and I understood that I am he

from whom I was separated ...

(CMC ff24:2)

The divine revelations and admonitions, which Mani received, were incompatible with some of the doctrinal tenets and practices of the Baptists. The CMC describes how Mani protested, for instance, against their harvesting (because it hurts the divine light elements present in the earth), against their gathering of fire-wood (idem) and, moreover, against their ritual ablutions. True purity, according to Mani, can only be achieved through special knowledge (Greek: gnosis). This gnosis is not obtained by outward observances, but by inner revelation. It is only through gnosis that we know the difference between good and bad, life and death, Light and Darkness (cf. CMC 84:10-17). According to Mani, the Baptists had gone wrong in observing a merely outward purification.

The Codex goes on to describe how Mani's severe criticism was accepted by some of his fellow community members, but was in the end rejected by the majority. A certain 'elder' (presbyteros) named Sita or Sitaios, together with the majority of the other elders, set up a synod deal with Mani's apparent apostacy. These leaders of the sect constituted its 'Sanhedrin' (Synhédrion) (cf. Reeves 1991) and certainly would have killed him had not his father Pattikios convinced them to spare Mani's life. After this event they left him to himself and during this time he prayed for guidance and support. The CMC continues by claiming that in the moment of his deepest despair his Syzygos appeared and encouraged him. In reply to Mani's desperate lamenting the 'Splendid One' (endoxótatos) says:

Not only to this religion (dógma)

you have been sent out,

but to every people and school of learning

and to every city and region.

For by you this Hope (elpis) will be made manifest

and it will be preached in every clime and every zone of the world

and in very great numbers men will accept your word.

Therefore,

come forward and travel about.

For I will be with you

as your helper and protector

in every place

where you proclaim everything I revealed to you.

(CMC 104-105)

Encouraged by these and similar words from his divine Twin, Mani made the final break with the Baptists. In the long passage handed down by Timotheos, Mani's mission statement, which is remarkably full of biblical references, runs as follows:

Thus,

according to the will of our Lord (despótès),

I came forward and left that Law (nómos)

in order to sow his most beautiful seed,

to light his brightest candles,

to redeem the living souls from their subjection to the rebels,

to walk in the world after the image of our Lord Jesus,

to throw on to the earth a sword, division and the blade of the spirit,

to drop the bread on my people

and to overcome the immeasurable shame which is in the world.

(CMC 107)

According to the Codex, Mani first went to Ctesiphon, where he was later joined by two fellow Baptists, who bore the typical Jewish names of Simeon and Abizachias. During Mani's trial before the Sanhedrin, they had already come to consider him to be the true Prophet, the recurrent heavenly figure that, according to these and other Jews and Jewish-Christians, had previously appeared in Adam, Seth(el), Enoch, Noah, Abraham, and also in Jesus, among others. Soon his father Pattikios became an adherent of Mani as well.

Here we may conclude our observations dealing with the origins of Mani'gnosis. Much more can be noted in regard to it, especially when looking into several other original Manichaean sources, such as those from Medinet Madi in Egypt (e.g. Wurst 1996; Richter 1998) and Turfan in Central Asia (e.g. Klimkeit 1993). Particularly from the pivotal information in the Cologne Mani Codex, we are able to gain a fresh insight. In summation we may state the following: It is now known that Mani was raised in a Jewish-Christian community of Baptists. He rejected their notions and practices regarding baptism, ablutions and Jewish Law. However, among the Elchasaites he heard about Jesus as the true prophet, a manifestation of God'glory (Greek: doxa, Hebrew: kabod) that was first embodied in Adam, then revealed itself to the Old Testament patriarchs, and finally was incarnated in the Messiah, Jesus.

This may explain the special place of Jesus in Mani's belief system. It is essential to note that Jesus was venerated, not only in Western Manichaean sources, but also in the sources from Central Asia and China (Waldschmidt \& Lentz 1926; Rose 1979). In the Coptic manuscripts, which were discovered in Medinet Madi in Egypt around 1930, the famous Coptic Psalm-Book (the second part of which was edited and translated by the British scholar Charles Allberry), contains many Psalms to 'Jesus' and Psalms to 'Christ'. Psalm-Book, the second part of which was edited and translated by the British scholar Charles Allberry, there are many Psalms to Jesus and Psalms to Christ. Two passages can attest to the essential 'Christocentric' character of these psalms. The first one is from a 'Psalm to Christ':

Christ, guide me: my Saviour, do not forget me.

I am the love (agápè) of the Father, being the robe clothing thee. Christ, guide me: my Saviour, do not forget me. My brethren are the Aeons and the Aeons of the Aeons. Christ, guide me, my Saviour, do not forget me. The air and the Land of Light -- they travailed with me. Christ, .... [etc.].

(Allberry 1938:116)

The second passage is from one of the famous 'Psalms of the Wanderers' (Psalmoì Sarakôtôn) in the Manichaean Psalm-Book:

I will] glorify thee, my God, I will glorify thee, my [giver

of] rest to everyone. My God, I will glorify thee.

[Stone of?] corner-stones, my God, I will glorify thee.

My giver of rest to everyone, my God, I will glorify thee.

Corner-stone unchanging, unaltering,

Foundation unshakeable,

sheep bound to the tree,

treasure hidden in the field,

Jesus that hangs to the tree,

Youth, son of the dew,

milk of all trees,

sweetness of the fruits (karpós),

eye of the skies,

guard of all treasures,

[power?] that bears the universe,

joy of all created things,

rest of the worlds (kosmós).

Thou art a marvel to tell,

Thou art within, thou art without,

Thou art above, thou art below,

Thou art near and far,

Thou art hidden and revealed,

Thou art silent and speakest too.

Thine is the glory,

the glory due to thee.

(Allberry 1938:155; Villey 1994:95)

To conclude in a few words: right from its inception the figure of Jesus had an important place in the gnosis of Mani. This Jesus was regarded as being the Jesus of Light who is an 'emanation' 
of the divine Nous (Intuition, Insight, Gnosis ). This Jesus, Burkitt (1925:43) wrote 'signified the divine redemption of man; divine nourishment for man; divine suffering for man'. In essence, these are gnostic-Christian ideas.

\section{MANICHAEISM AND WESTERN CHRISTIANITY: THE CASE OF AUGUSTINE}

Did this Manichaean Gnosis, once a world religion and alternative Christian Church, exert any influence on 'orthodox' mainstream Christianity and thus on the tradition of the main Christian Churches? In this context, it is perhaps the most intriguing question, but I will only briefly touch upon it here. It should be stressed that many of its aspects still await exploration in more detail. Yet, some references can be made to a number of special studies.

Our focal point is the North African bishop Augustine (354-430), the greatest and most influential Father of the Church. He was once an adherent of Manichaeism in North Africa, as well as during his sojourn in Rome. It is also possible to speculate that he might have been involved in Manichaeism as a doubting seeker of 'truth' when he was in Milan.

The Manichaean phase of his life started in 373 and lasted for more than ten years. After his Manichaean years, Augustine, now having reconverted to the Catholic Christianity of which he had become a catechumen in his early youth (Van Oort 1991:25-30) wrote many books and tracts against his former co-religionists. Nevertheless, it was near the end of his life that he was again accused of Manichaeism because of his view regarding sexual concupiscence and original sin, among other views he held.

Even as an Ethiopian (i.e., a black man - and Augustine was from Africa) cannot change his skin nor the leopard his spots, even so it is impossible for you to wipe out your Manichaean past (quote in: Augustinus, Contra Iulianum opus imperfectum IV 42 )

There seems to be some truth in this scathing, perhaps even racist remark, made by Augustine's colleague and severe opponent, the Catholic Bishop Julian of Eclanum from Southern Italy. Three main possible areas of the influence of Manichaeism on the Western Church could be discerned and about each one a few observations may be made.

Firstly, there are some striking similarities between Augustine's view of sexual concupiscence and original sin and the Manichaean attitude to sex and sin (Adam 1958; Van Oort 1989). Both views are very negative, in particular with regard to the 'randomness' of the sexual impulse and, moreover, both stress that this randomness is sin. They agree that in its randomness, in itsmotus inordinatus 'movement' (motus inordinatus), the sinful nature of sexual desire reveals itself prominently, and that sin is transmitted through this sexual desire.

Secondly, there are many similarities between Augustine's famous and very influential doctrine of the two 'cities' or 'kingdoms' (Latin: ciuitates) and the dualistic Manichaean view of the two 'realms', 'cities' or 'kingdoms'. Everyone who reads Augustine's famous City of God, and its Book XI in particular, will be struck by such similarities. These similarities in thought and even terminology seem to serve as justification to observe direct influences here (Adam 1958; Van Oort 1991:212-228; Van Oort 1996a).

The third and probably most important area of influence seems to be Augustine's own spirituality. Nowhere in the Early Church before 400 does there appear to be, in my opinion, such a tender and appealing piety, along with such a prominent place given to Christ, as in the writings of Augustine and the Manichaean sources. When reading Augustine's Confessions, one is more than once reminded of the Manichaean Psalms (Van Oort 1997; Van Oort 2002; Kotzé 2004). He tells us that he also 'learned' from the
Manichaeans and it is quite certain that he had sung their psalms (Van Oort 1991:35). Some essential features of Augustine's own spirituality reflect how he has served as a 'conduit' through which the influences of Manichaeism flowed to effect a lasting impact on Christian spirituality as a whole.

\section{REFERENCES}

Adam, A., 1958, 'Das Fortwirken des Manichäismus bei Augustin', Zeitschrift für Kirchengeschichte 9, 1-25.

Allberry, C.R.C., 1938, A Manichaean Psalm-Book (Manichaean Manuscripts in the Chester Beatty Collection, Volume II), Stuttgart, Kohlhammer.

Augustinus, Contra Iulianum opus imperfectum: J.P. Migne (ed.), Patrologiae Cursus completus, Series Latina, volumen 45, Paris: Montrouge 1841.

Burkitt, F.C., 1925, The Religion of the Manichees, Cambridge University Press, Cambridge.

Colpe, C., 1961, Die Religionsgeschichtliche Schule. Darstellung und Kritik ihres Bildes vom gnostischen Erlösermythus, VandenHoeck und Ruprecht, Göttingen.

De Stoop, E., 1909, Essai sur la diffusion du manichéisme dans l'empire romain (Université de Gand, Recueils de travaux publiés par la Faculté de Philosophie et Lettres 38), Gand: E. van Goethem.

Dodge, B., 1970, The Fihrist of al-Nadim. A Tenth-Century Survey of Muslim Culture, vol. II (Records of Civilization; Sources and Studies 83), Columbia University Press, New York.

Frankfurter, D., 1997, 'Apocalypses Real and Alleged in the Mani Codex', Numen 44, 60-73.

Gruenwald, I., 1983, 'Manichaeism and Judaism in Light of the Cologne Mani Codex', Zeitschrift für Papyrologie und Epigraphik 50, 29-45.

Henrichs, A. E Koenen, L., 1970, 'Ein griechischer Mani- Codex (P. Colon. inv. nr. 4780)', Zeitschrift für Papyrologie und Epigraphik 5, 97-216.

Kawerau, P., 1967, Geschichte der Alten Kirche, N.G. Elwert Verlag, Marburg.

Klimkeit, H-J., 1993, Gnosis on the Silk Road. Gnostic Texts from Central Asia, Harper, San Francisco.

Koenen, L. E Römer, C., 1988, Der Kölner Mani-Kodex: Über das Werden seines Leibes: Kritische Edition aufgrund der von A. Henrichs und L. Koenen besorgten Erstedition, Westdeutscher Verlag, Opladen.

Kotzé, A., 2004, Augustine's Confessions. Communicative Purpose and Audience (Supplements to Vigiliae Christianae LXXI) E.J. Brill, Leiden-Boston.

Lieu, S.N.C., 1992, Manichaeism in the Later Roman Empire and Medieval China (Wissenschaftliche Untersuchungen zum Neuen Testament 63), Tübingen: J.C.B. Mohr (Paul Siebeck).

Lieu, S.N.C., 1994, Manichaeism in Mesopotamia and the Roman East (Religions in the Graeco-Roman World 118), E. J. Brill, Leiden-New York-Köln.

Lieu, S.N.C., 1998, Manichaeism in Central Asia and China (Nag Hammadi and Manichaean Studies 45), E. J. Brill, LeidenBoston-Köln.

Luttikhuizen, G.P., 1985, The Revelation of Elchasai. Investigations into the Evidence for a Mesopotamian Jewish Apocalypse of the Second Century and its Reception by Judaeo-Christian Propagandists, (Texte und Studien zum Antiken Judentum 8), J.C.B. Mohr (Paul Siebeck), Tübingen.

Ort, L.J.R. 1967, Mani. A religio-historical description of his personality, E.J. Brill, Leiden.

Petersen, W., 2005/2008: 'Tatian', Die Religion in Geschichte und Gegenwart, vol. VIII, Tübingen: Mohr Siebeck (reprint Tübingen: Mohr Siebeck 2008), 47.

Reeves, J.C., 1991, "The "Elchasaite" Sanhedrin of the Cologne Mani Codex in Light of Second Temple Jewish Sectarian Sources', Journal of Jewish Studies 42, 68-91.

Reeves, J.C., 1996, Heralds of That Good Realm. Syro-Mesopotamian Gnosis and Jewish Traditions (Nag Hammadi and Manichaean Studies XLI), E.J. Brill, Leiden-New York-Köln.

Richter, S.G., 1998, The Manichaean Coptic Papyri in the Chester Beatty Library: Psalm Book, Part II, Fasc. 2: Die Herakleides- 
Psalmen (Corpus Fontium Manichaeorum, Series Coptica, I, Liber Psalmorum, Pars II, Fasc. 2), Brepols Publishers, Turnhout.

Römer, C., 1994, Manis frühe Missionsreisen nach der Kölner Manibiographie. Textkritischer Kommentar und Erläuterungen zu p. 121 - p. 192 des Kölner Mani-Kodex, Westdeutscher Verlag, Opladen.

Rose, E., 1979, Die manichäische Christologie, Harassowitz, Wiesbaden.

Van Oort, J. E Quispel, G., 2005, De Keulse Mani-Codex. Vertaald, ingeleid en toegelicht (Pimander 11), In de Pelikaan, Amsterdam.

Van Oort, J., 1989, 'Augustine on sexual concupiscence and original sin', in: E. Livingstone (ed.), Studia Patristica XXII, Leuven, Peeters, 382-386.

Van Oort, J., 1991, Jerusalem and Babylon. A Study into Augustine's City of God and the Sources of his Doctrine of the Two Cities (Supplements to Vigiliae Christianae 14), E.J. Brill, LeidenNew York-København-Köln.

Van Oort, J., 1996a: 'Manichaeism in Augustine's De ciuitate Dei', in: E. Cavalcanti (ed.), Il 'De ciuitate Dei': L'opera, le interpretazioni, l'influsso, Roma-Freiburg-Wien, Herder, 193214.

Van Oort, J., 1996b: 'The Study of the Cologne Mani Codex, 19691994', Manichaean Studies Newsletter 13, 22-30.

Van Oort, J., 1997, 'Manichaeism and anti-Manichaeism in Augustine's Confessiones', in L. Cirillo E A. Van Tongerloo (eds.), Atti del Terzo Congresso Internazionale di Studi 'Manicheismo e Oriente Cristiano Antico', Arcavacata di Rende Amantea, 31 agosto - 5 settembre 1993 (Manichaean Studies III), Turnhout: Brepols, 235-248.
Van Oort, J., 2002/2008, 'Manichäismus', Die Religion in Geschichte und Gegenwart, vol. V, Tübingen: Mohr Siebeck (reprint Tübingen, Mohr Siebeck 2008), 732-741.

Van Oort, J., 2004, 'The Paraclete Mani as the Apostle of Jesus Christ and the Origins of a New Christian Church', in A. Hilhorst (ed.), The Apostolic Age in Patristic Thought (Supplements to Vigiliae Christianae LXX), Leiden-Boston: E.J. Brill Academic Publishers, 139-157.

Van Oort, J., 2008, 'Elkesaites', Religion, Past and Present, Volume IV, Leiden-Boston, E.J. Brill Academic Publishers, 416.

Van Tongerloo, A. E Van Oort, J., 1995, The Manichaean NOY.

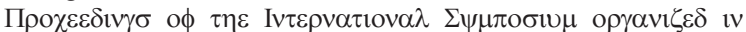

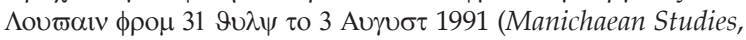
Vol. 2), Louvain, International Association of Manichaean Studies.

Verheule, A.F., 1973, Wilhelm Bousset. Leben und Werk, Amsterdam, Ton Bolland.

Villey, A., 1994, Psaumes des errants. Écrits manichéennes du Fayyum (Sources gnostiques et manichéennes 4), Paris, Cerf.

Waldschmidt, E. E Lentz, W., 1926: Die Stellung Jesu im Manichäismus, Berlin: Verlag der Akademie der Wissenschaften.

Wurst, G., 1996, The Manichaean Coptic Papyri in the Chester Beatty Library: Psalm Book, Part II, Fasc. 1: Die Bema-Psalmen (Corpus Fontium Manichaeorum, Series Coptica, I, Liber Psalmorum, Pars II, Fasc. 1), Turnhout: Brepols Publishers. 